Volume 8, No.1.5, 2019

International Journal of Advanced Trends in Computer Science and Engineering

Available Online at http://www.warse.org/IJATCSE/static/pdf/file/ijatcse2981.52019.pdf

https://doi.org/10.30534/ijatcse/2019/2981.52019

\title{
Implemented the Principles of User Interface Design in Electronic Ordering System
}

\author{
Siti Nurul Hayatie Ishak ${ }^{1}$, Intan Nazurah Zakaria ${ }^{2}$ \\ ${ }^{1}$ Universiti Teknologi MARA, Malaysia, Faculty of Computer and Mathematical Sciences, \\ sitinurul@uitm.edu.my \\ ${ }^{2}$ Universiti Teknologi MARA, Malaysia, Faculty of Computer and Mathematical Sciences, \\ intan.zakaria.509@gmail.com
}

\begin{abstract}
Practically, the organization needs to ensure the flow of activities from acquiring raw materials, to the production until distribution to the customer are well managed and cost effective. All information available throughout the activity needs to be stored in an efficient way. However, managing the information related activity can be challenging for many small medium enterprises (SMEs) who rely on paper-based method. Despite of lacking in term of manpower to handle the business related activity, the company also faces difficulty to manage their daily orders, calculate their profits and to generate sales report. This subsequently gives difficulty to the manager to measure the company performance and to assist in making quick decisions to manage company production. Thus, an electronic ordering system (EOS) is developed to collect, store, modify and retrieve data transactions to improve the ordering process for the company by providing technological solution that can help the organization to improve the ordering process. This system is developed by implementing the principle of user interface model emphasizes on learnability and robustness and embedded adapted waterfall model as a system development methodology. Last but not least, the system has been tested for its functionality and usability with several experts and thirty potential users. As a result, the construct for learnability of the users towards the system get the highest mean by 4.60 with standard deviation (SD) is 0.50 . Conclusively, implementing the principles user interface design can assist users to learn the system more easily and achieve maximum performance by using the system.
\end{abstract}

Key words: Ordering System, Principles of User Interface Design, Small Medium-sized Enterprises (SME), Learnability, Robustness

\section{INTRODUCTION}

Order processing is a process where the order data is gathered from the customer directly or by the customer service employee and it is stored in the central database and will be sent to the accounting and shipping department [1]. Order processing is related to four main components of the supply chain which are supplier, factory, distributor, and retailer. The retailer and distributor are placing orders; whereas, factory and supplier work in collaboration with one another in order to fulfill these orders. This research focuses on local SME

particularly a manufacturer company that produces the instant noodles. The business profit is earned by supplying and selling instant noodles to the distributor, retail shops and individual customer. Due to the small size of the business, the company faces an inadequate problem of employees to handle business processes. The staff should perform multiple tasks to fulfill the instant noodle ordering process. The decision to recruit new staff also comes at a cost, and the research found that a further 27 percent of small businesses are worried about how they will fund the hiring of new employees [2].

Currently, the company recorded the purchase of their product in cash book and bill book. Cash book for customer who pay in cash, whereas, bill book for customer who pay in installments. Activity to purchase the raw materials, equipment, and other costs will keep in a file. Some purchasing process of the raw materials is made in regular retail outlets that do not have a receipt such as a flour shop. All receipts are stored in a book or file may also be lost due to the fade of ink on the paper. The fading raw material receipts in the file have made it difficult for staff to read and search information. When the receipt is first printed, it will look sharp, crisp and clean, but it can fade over time [3].

Last but not least, the management faces difficulty to generate a quick report. The reports are useful for business to see the performance. If the information is incorrect, this will cause the company to misinterpret the business performance for future improvements.

The customer for this company can be categorized into distributor, retailer, and individual customer. Distributor will collect the products and sells them in the quantity set out in the contract each month to the customer like retailers and entrepreneurs. The order quantity made by distributor to the company is fixed every month as per agree in the agreement. Distributor also disseminates catalogs to other retailers who may have potential to buy the instant noodle. For individual customers, they can go directly to the company to buy the product or contact the company to make an order. Some orders made by individual customer will be delivered by the staff to them based on the agreement made by both parties. Figure 1 illustrates the business supply chain for the company. 


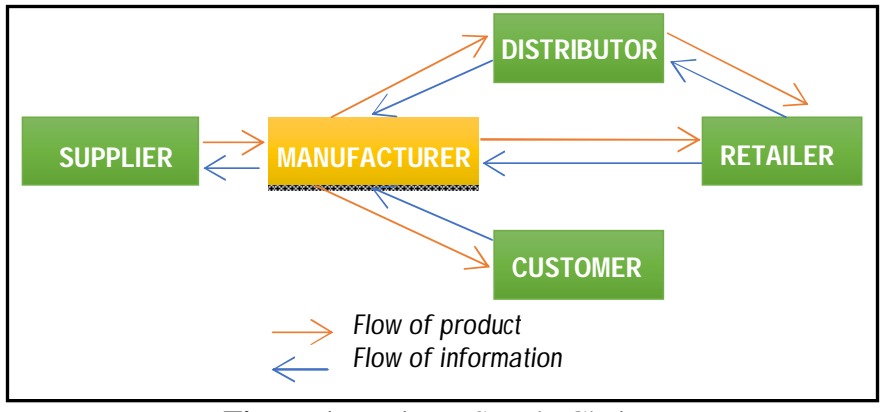

Figure 1: Business Supply Chain

Thus, EOS is developed to facilitate the company to manage their orders by giving the customer an opportunity to complete their order through the system. The ordering system also facilitates the factory to communicate with supplier to purchase raw materials. Figure 2 illustrate system's scope.

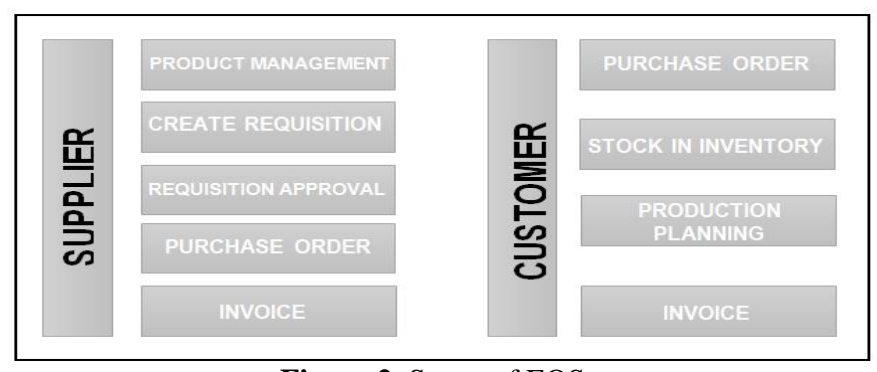

Figure 2: Scope of EOS

\section{RELATED WORKS}

The advancement in technology has given a lot of benefits to manufacturing company. According to IDC, information technology has allowed configured systems manufacturers to create greater efficiencies in their organizations. Based on the IDC survey made in 2004 with several manufacturers company particularly from electronic component manufacture, it stated that four major company's strategic priorities are contribute related with increasing sales and marketing, lessen order to delivery time, minimize cost of manufacturing and manage inventory more effectively [4].This is also supported by [13], the use of modern technologies and applications can reduce more times and money by improving the performance and accuracy, better presentation of information and serving of the environment [13]. These objectives can be achieved by configured electronic systems manufacturers.

Smith [5] stated that a manual ordering system take more cycle times for processing where later subsequently leads to delay in shipping, increase more costs, and poor customer relationships due to failure to meet service-level agreements (SLA)[5]. Paper-based order processing only complicates the situation and drives up costs. This will inconvenience the customer to purchase the product and consequently will choose to purchase the product that has the same features in an easier way [5].

Online ordering system is a system to capture customer demand and record the type of materials, components and additional information for company to predict the demand [6].
When the customer wants to buy a product in the websites, organization should make sure that they deliver it quickly to customer. This is because most of customers do not like to wait too long to get the products that they have bought and usually the maximum delivery period cannot be more than a week except on certain days, for example, on a festive day. For some items such as physical products online, it needs for fast and efficient delivery to the customer. An effective fulfillment service quality is capable of controlling all of the stages from processing the order to delivery to their customer subsequently lead to improve in customer satisfaction. As stated by [12], service quality significantly affects customer satisfaction and has relation with self-service technology [12]. This is supported by [5] where online ordering system will enhance the customer experience with the manufacturer through a customer service representative (CSRs). CSR can resolve issues regarding customer problems more quickly because they have complete electronic access to documentation [5]. In the field of human-computer interaction, there is interface design rules used to support usability that helps to engage customer by providing better user interface design for the system. Usability is a web design approach, by which it determines how difficult for a user to learn and access an application. These principles are divided into three main categories which are learnability, flexibility, and robustness [7]. Learnability is the capability of an interactive system to enable users to learn how to use it initially, and then exploit all features offered easily. Meanwhile, flexibility relates to the multiplicity of ways that users and system exchange information. In the learnability, this project focuses on three specific principles that support learnability which are predictability, familiarity, and consistency. Table 1 below describes the explanation of the principles.

Table 1: Summary of principles affecting learnability [11]

\begin{tabular}{|l|l|}
\hline Principle & Definition \\
\hline Predictability & $\begin{array}{l}\text { Support for the user to determine the effect of } \\
\text { future action based on past interaction history }\end{array}$ \\
\hline Familiarity & $\begin{array}{l}\text { The extent to which a user's knowledge and } \\
\text { experience in other real-world or computer based } \\
\text { domains can be applied when interacting } \\
\text { with a new system }\end{array}$ \\
\hline Consistency & $\begin{array}{l}\text { Likeness in input-output behavior arising from } \\
\text { similar situations or similar task objectives }\end{array}$ \\
\hline
\end{tabular}

Robustness is the level of support provided to the users in determining successful achievement and assessment of goals. This project focuses on the three specific principles that affect robustness which are recoverability, responsiveness, and task conformance. Table 2 below describes the explanation of the principles.

Table 2: Summary of principles affecting robustness [11]

\begin{tabular}{|l|l|}
\hline Principle & Definition \\
\hline Recoverability & $\begin{array}{l}\text { Ability of the user to take corrective action once } \\
\text { an error has been recognized }\end{array}$ \\
\hline Responsiveness & $\begin{array}{l}\text { How the user perceives the rate of } \\
\text { communication with the system }\end{array}$ \\
\hline $\begin{array}{l}\text { Task } \\
\text { Conformance }\end{array}$ & $\begin{array}{l}\text { The degree to which the system services } \\
\text { support all of the tasks the user wishes to } \\
\text { perform and in the way that the user } \\
\text { understands them }\end{array}$ \\
\hline
\end{tabular}


The components, reviews, and features on similar ordering systems have been identified and compared in Table 3. For the proposed system, the features that will be added and provided to the system were purchase order module, inventory module, production module, and invoice module. Table 3 shows modules and components related to the scope of the project to be included in the proposed system.

Table 3: Comparison of features of EOS with Similar Systems

\begin{tabular}{|c|c|c|c|c|}
\hline \multirow[b]{2}{*}{$\begin{array}{c}\text { Features of E-ordering } \\
\text { System }\end{array}$} & \multicolumn{3}{|c|}{ Similar Systems } & \multirow[b]{2}{*}{ EOS } \\
\hline & $\begin{array}{c}\text { Mega- } \\
\text { Ventory } \\
{[8]}\end{array}$ & $\begin{array}{c}\text { Orderhive } \\
\text { [9] }\end{array}$ & $\begin{array}{c}\text { Zoho } \\
\text { Inventory } \\
{[10]}\end{array}$ & \\
\hline \multicolumn{5}{|l|}{ Purchase Order Module } \\
\hline Customer Management & l & $\mathbf{x}$ & $\mathbf{x}$ & I \\
\hline Catalog Management & I & 1 & $\mathbf{x}$ & I \\
\hline Reporting & 1 & 1 & $\mathbf{x}$ & 1 \\
\hline \multicolumn{5}{|l|}{ Inventory Module } \\
\hline Re-order Management & I & $\mathbf{x}$ & $\mathbf{x}$ & I \\
\hline Supplier Management & I & I & 1 & I \\
\hline Reporting & l & I & I & I \\
\hline \multicolumn{5}{|l|}{ Production Module } \\
\hline Allocation & 1 & 1 & $\mathbf{x}$ & I \\
\hline $\begin{array}{l}\text { Sales \& Operations } \\
\text { Planning }\end{array}$ & I & I & $\mathbf{x}$ & I \\
\hline Item Management & I & I & $\mathbf{x}$ & I \\
\hline Order Management & I & 1 & $\mathbf{x}$ & 1 \\
\hline Quantity Control & $\mathbf{x}$ & $\mathbf{x}$ & $\mathbf{x}$ & 1 \\
\hline Reporting & $\mathbf{x}$ & $\mathbf{x}$ & $\mathbf{x}$ & 1 \\
\hline \multicolumn{5}{|l|}{ Invoice Module } \\
\hline Purchasing & $\mathbf{x}$ & I & I & I \\
\hline Reporting & 1 & $\mathbf{x}$ & $\mathbf{x}$ & 1 \\
\hline
\end{tabular}

\section{METHODOLOGY}

This project consists of five phases which are knowledge acquisition, project initiation, project delivery, project close and project evaluation. For system development, EOS implemented adaptive waterfall model and it is adapted in the first five phase of the project. The preliminary study is conducted at the early phase to identify the current business process and problems related with ordering process. The project delivery includes the process of capturing the user requirements and analyzing the system requirements to assist for designing the system. The most vital phase is the implementation phase where the designs of the system being executed and followed by the testing of the system. Meanwhile, the two last phases are focusing on documentation. Figure 3 illustrates the project framework for the proposed system project.

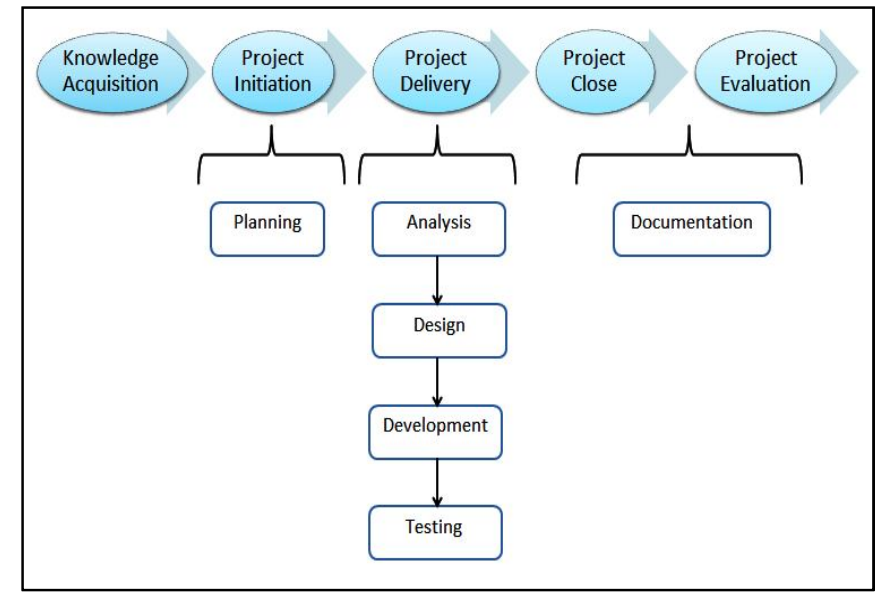

\subsection{System Design}

Figure 3: Project Framework

There are several users who can access to the system. They are manager, staff, supplier, and customer. The scope for customer in this system covers four main processes which are purchase order, production planning, stock in inventory, and invoice. Meanwhile, the scope for supplier of the system covers five main processes which are upload product; create requisition, requisition approval, purchase order, and invoice. Figure 4 illustrate the context diagram for EOS.

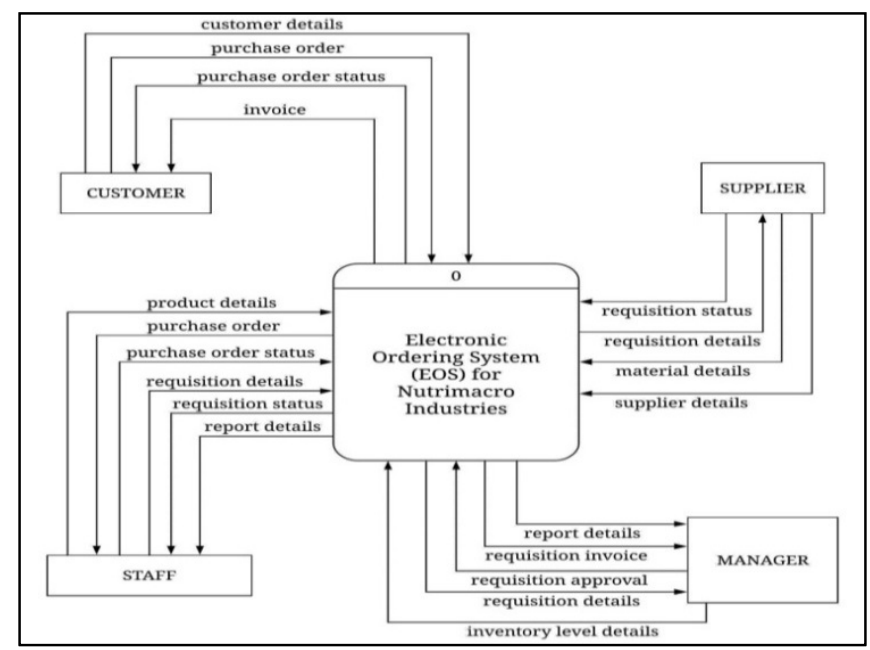

Figure 4: Context Diagram for EOS

\subsection{System Modules}

The main purpose of EOS is to enhance the ordering process for the company specifically for the customer, staff, supplier, and manager. This system catered the process whereby it starts from new customer are registering in the system until completion of the requisitions process from the supplier.

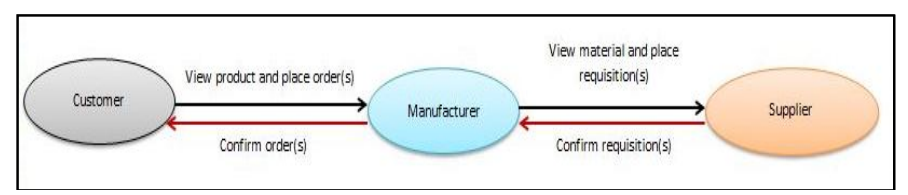

Figure 5: Process flow of EOS 
Before submitting requisitions to the supplier, the manager will approve the order requisition made by the staff. The manager will make a payment when the invoice is generated by the system once the raw material has arrived at the factory. Customer can also leave messages to the staff in the provided notes space. Then, the system will generate the order and send it to the staff via the system. Figure 6 shows Purchase Order page for the customer to buy the products.

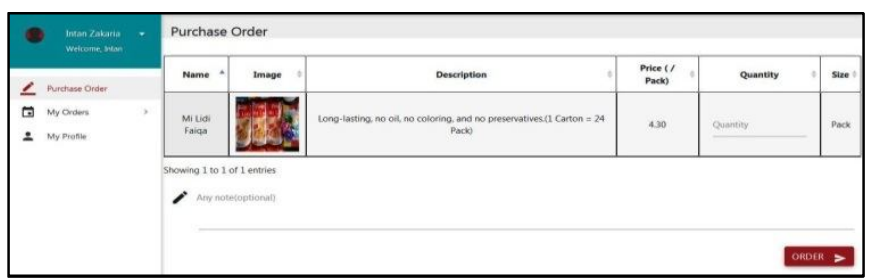

Figure 6: Purchase Order Page

Then, if payment has not been made, the staff should inform the customer to make the payment immediately. Staff can only confirm order if payment status is 'Paid'. Staff can also click on the order number to view the details of orders made by the customer. Figure 7 shows Verify Order page for the staff to confirm on the product ordered by the customer.

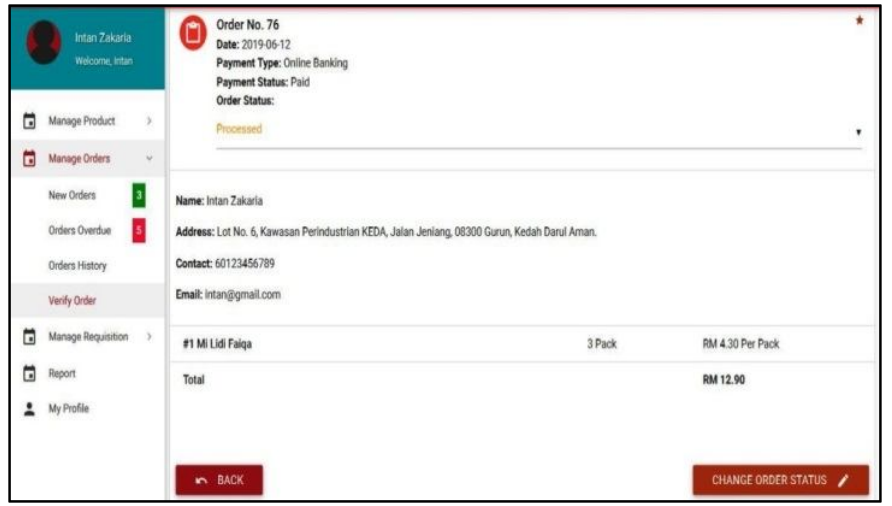

Figure 7: Verify Order Page

Next, manager can view a list of raw materials and product which are in the factory's inventory. The manager can update the inventory level of each raw material and product in the inventory. Staff will be able to send requisition form to the manager if the inventory level reaches the point that needs to be reorder. The requisition will be sent to the manager for approval before being sent to the supplier. Furthermore, the manager can give approval either to approve or reject the order with reasonable reasons on the requisitions for raw materials made by the staff. Figure 8 shows Approval page for the manager to provide the approval of the requisition made by the staff either accept or reject with reason that reasonable.

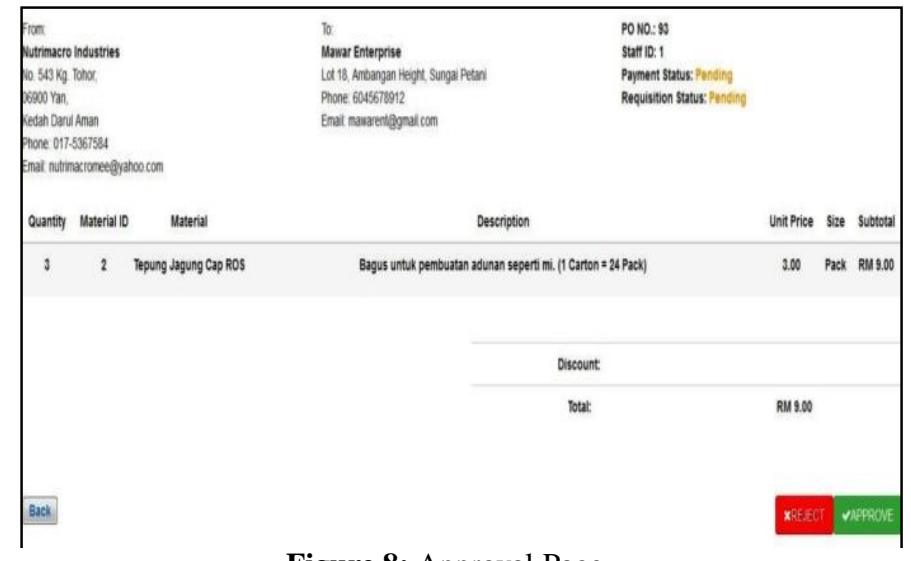

Figure 8: Approval Page

Besides that, supplier can also manage requisition made by the staff. The supplier can change the status of the request even though the payment has not been made by the factory. Figure 9 shows Incomplete Requisition page for the supplier to provide confirmation of the status of the requisition made by the factory where it has been approved by the manager.

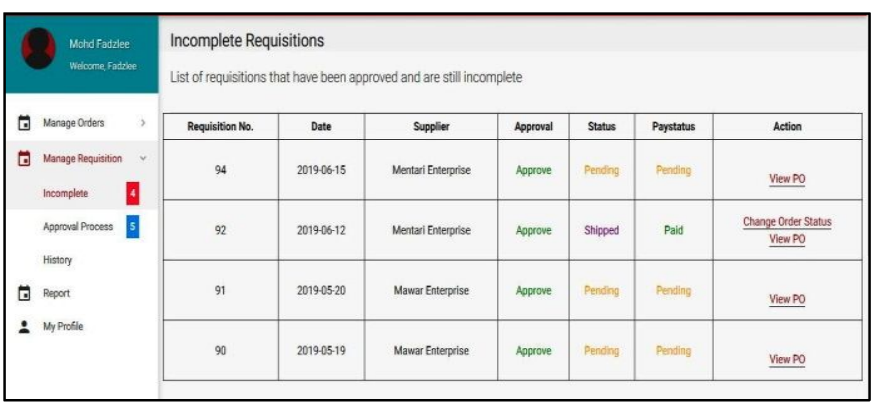

Figure 9: Incomplete Requisition Page

In addition, the staff may also confirm the requisition if the material has arrived at the factory. The status will be changed to 'Received' only when the raw material ordered has arrived at the factory. Last but not least, all requisition lists are approved by the manager and he or she needs to make a payment for the approved purchase order. The manager can only make payment if the staff has confirmed the raw material has arrived at the factory through this system. Figure 10 shows Make Payment page for the manager to make a payment to the supplier when the requisition status has been changed to 'Received'.

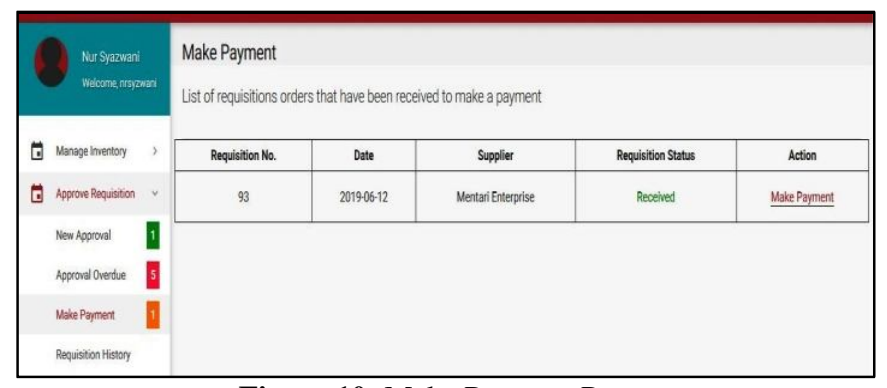

Figure 10: Make Payment Page 
In order to view the performance of the company, the Report page is provided for the staff and manager to see the summary of orders made by the customer as well as the expenses of the company.

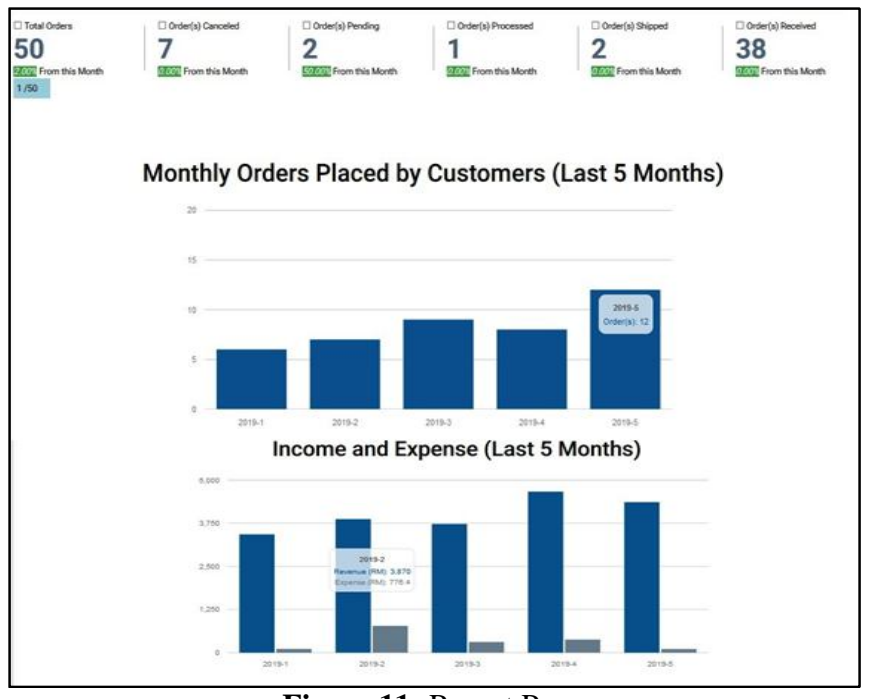

Figure 11: Report Page

\section{RESULTS AND DISCUSSION}

The development of EOS implemented the principles of user interface design which originally modeled by Alan Dix, Janet Finlay, Gregory D. Abowd, and Russell Beale [11]. This project emphasizes on two principles out of three which are learnability and robustness. In the learnability, this project focuses on three specific principles that support learnability which are predictability, familiarity, and consistency. Moreover, in the robustness there are three characteristics which are recoverability, responsiveness, and task conformances have been implemented in the system. Table 4 shows the features adapted based on the theory used which is the principle of user interface design.

Table 4: Features Adapted in EOS Based on Principles of User Interface Design

\begin{tabular}{|l|l|l|}
\hline \multicolumn{2}{|c|}{$\begin{array}{c}\text { Principles of User Interface } \\
\text { Design }\end{array}$} & \multicolumn{1}{c|}{ Features } \\
\hline Learnability & Predictability & $\begin{array}{l}\text { - Purchase order on customer page } \\
\text { - Purchase orders on staff page for } \\
\text { raw materials }\end{array}$ \\
\cline { 2 - 3 } & Familiarity & $\begin{array}{l}\text { - Login page. Use application menus } \\
\text { which are "login" and "cancel". } \\
\text { Information displayed below the } \\
\text { box to give users information }\end{array}$ \\
\cline { 2 - 3 } & Consistency & $\begin{array}{l}\text { - Use consistent button "Back" in } \\
\text { View Order page, Verify Order } \\
\text { page. }\end{array}$ \\
\hline Robustness & Recoverability & $\begin{array}{l}\text { The system able to fix when the user } \\
\text { cannot undo the current process. For } \\
\text { example, the system will support if } \\
\text { the user want to "undo" and "redo" } \\
\text { the current process. }\end{array}$ \\
\hline
\end{tabular}

\begin{tabular}{|l|l|l|}
\hline Responsiveness & $\begin{array}{l}\text { The system will limit of human } \\
\text { waiting, and the system give } \\
\text { indication to user that system has } \\
\text { received the request for action and i } \\
\text { is working on response. For } \\
\text { example, the system generates the } \\
\text { details of the purchase order after } \\
\text { click button submit on order form } \\
\text { page. }\end{array}$ \\
\hline Task & $\begin{array}{l}\text { The system able to complete the } \\
\text { process from the supplier side until } \\
\text { Conformance } \\
\text { system support all the file upload } \\
\text { and continue the next step until } \\
\text { complete. }\end{array}$ \\
\hline
\end{tabular}

There were 30 respondents participated in testing and evaluation phase. Several sets of test plans are distributed to 30 respondents. The test plan covers demographic profile of the users, and the six constructs of contents and sales reporting. The users are required to scale the system based on the scale provided which are 1 for strongly disagree, 2 for disagree, 3 for not sure, 4 for agree and 5 for strongly agree. Majority of respondents for this testing are male with total of 17 respondents $(56.7 \%)$ while female with 13 respondents $(43.3 \%)$. The ages of respondents are from 18-33 years and above. The education level is varies from SPM to degree level and employment status is from student, self-employed and employed. The test plan are divided into six constructs which are user interface(A), usability (B), efficiency (C), learnability (D), robustness (E) and satisfaction $(F)$. Construct D and E are derived from the principle of user interface design. Table 5 shows the summary of demographic profile of respondents.

Table 5: Summary of Demographic Profile of Respondents

\begin{tabular}{|r|c|c|c|}
\hline \multirow{2}{*}{$\begin{array}{r}\text { Demographics } \\
\text { Respondent's } \\
\text { Gender }\end{array}$} & Items & $\begin{array}{c}\text { Total } \\
\text { respondents } \\
(\mathbf{N}=\mathbf{3 0})\end{array}$ & $\begin{array}{c}\text { Percentage } \\
(\mathbf{\%})\end{array}$ \\
\cline { 2 - 4 } & Male & 13 & 43.3 \\
\hline Respondent's Age & $18-20$ & 17 & 56.7 \\
\cline { 2 - 4 } & $21-23$ & 12 & 3.3 \\
\cline { 2 - 4 } & $24-26$ & 3 & 40 \\
\cline { 2 - 4 } & $27-29$ & 4 & 13.3 \\
\cline { 2 - 4 } & $30-32$ & 4 & 13.3 \\
\cline { 2 - 4 } & $\begin{array}{c}33 \text { years and } \\
\text { above }\end{array}$ & 6 & 20 \\
\hline Education Level & SPM & 20 & 66.67 \\
\cline { 2 - 4 } & STPM & 10 & 33.33 \\
\cline { 2 - 4 } & $\begin{array}{c}\text { Pre-Diploma/ } \\
\text { Diploma }\end{array}$ & 8 & 26.7 \\
\cline { 2 - 4 } & Degree & 15 & 50 \\
\hline Employment Status & Student & 12 & 40 \\
\cline { 2 - 4 } & Self-employed & 4 & 13.3 \\
\cline { 2 - 4 } & Employed & 14 & 46.7 \\
\hline
\end{tabular}

The suitable metrics for learnability to measure effectiveness, efficiency and satisfaction are include the percentage of functions learned, time to learn and rating scale for ease of learning [11]. Based on the results, the highest mean value is 4.60 for construct $\mathrm{D}$ with standard deviation of 0.50 . This construct is one of the principles in the theory that have been implemented in this system. This shows that users 
can learn easily where they can start interaction effectively and achieve maximum performance by using this system. The system is evaluated based on the ease of use of the flow of the system, understandable of the features and system interaction, familiarity and adaptability of the system interface.

Table 6: Results for Learnability Construct

\begin{tabular}{|c|l|c|c|c|c|}
\hline \multicolumn{6}{|c|}{ SECTION D: LEARNABILITY } \\
\hline Items & \multicolumn{1}{|c|}{ Questions } & Mode & Median & Mean & SD \\
\hline D1 & $\begin{array}{l}\text { It is easy for me to } \\
\text { learn how to operate } \\
\text { the system. }\end{array}$ & 5 & 5 & 4.60 & 0.50 \\
\hline D2 & $\begin{array}{l}\text { The feature on the } \\
\text { system is easy to } \\
\text { understand. }\end{array}$ & 5 & 5 & 4.53 & 0.51 \\
\hline D3 & $\begin{array}{l}\text { The interaction with } \\
\text { the system is clear } \\
\text { and understandable. }\end{array}$ & 5 & 5 & 4.60 & 0.50 \\
\hline D4 & $\begin{array}{l}\text { I easily remember } \\
\text { how to use the } \\
\text { system. }\end{array}$ & 5 & 5 & 4.60 & 0.50 \\
\hline D5 & $\begin{array}{l}\text { It is easy to become } \\
\text { skillful at using the } \\
\text { system. }\end{array}$ & 4 & 4.50 & 4.50 & 0.51 \\
\hline D6 & $\begin{array}{l}\text { The system can be } \\
\text { easily adaptable by all } \\
\text { level of users. }\end{array}$ & 4 & 4.50 & 4.50 & 0.51 \\
\hline
\end{tabular}

The second highest is followed by construct $\mathrm{E}$ and $\mathrm{F}$ for robustness and satisfaction with mean 4.57 respectively. Figure 12 shows the overall result for the six constructs. The range of mean for this result is between values of 4.60 to 4.47 .

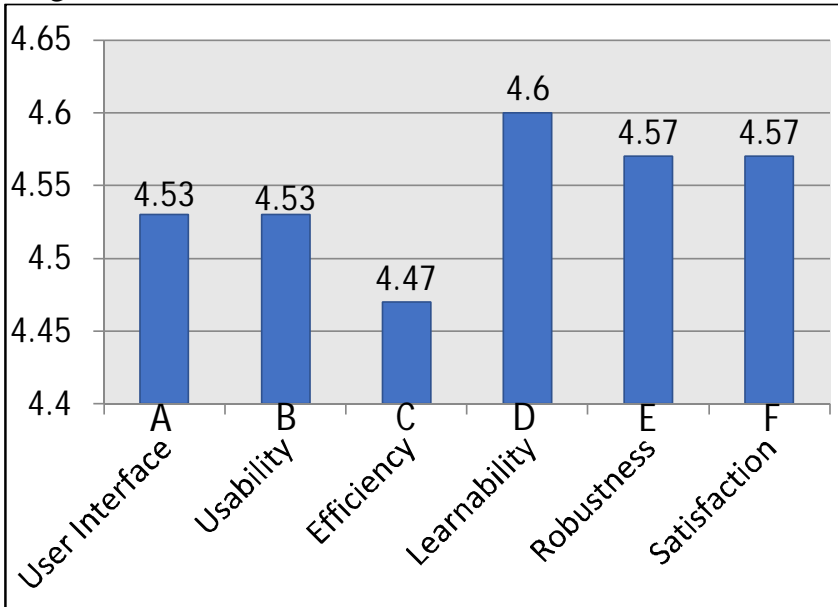

Average M ean Value for User Evaluation

Figure 12: Average Mean Value for Six Constructs

\section{CONCLUSION}

The development of EOS has assisted in contributing a computerized system to facilitate the company to fulfill the orders made by the customer more effectively and efficiently. Besides that, the company can maintain their relationship with suppliers and ensure supply for raw materials are consistent to avoid shortage in production for a period of time subsequently lead in reducing the problem of maverick buying. Furthermore, the principles of user interface design which are learnability and robustness have been implemented in the system which the result shows that the users agreed the importance of these two elements to be embedded in this system. As a conclusion, it is argued that this system can enhance the ordering process for manufacturing company to acquire the necessary goods, and implementing the principles user interface design can assist users to learn the system more easily and achieve maximum performance by using this system.

\section{REFERENCES}

1. Ingram David. What Is the Definition of Order Processing Systems? In Houston Chronicle, 2018.

2. Conway Chris. The challenges of hiring for a fast growing SME, in Accounts and Legal: Small business accountants, 2018.

3. Conrad Bonnie. How to Recover a Faded Cash Register Receipt, in Houston Chronicle, 2009.

4. IDC. Increasing Supply Chain Responsiveness Among Configured Electronic Systems Manufacturers, IDC White Paper, Author Meredith Wallen, 2004.

5. Smith, S. (2018). Manufacturers And Automated Order Processing: The Benefits, in Manufacturing.net, 2018

6. Rahmatian, S. Transaction Processing Systems, in Encyclopedia of Information Systems, Vol 4 pp 479, Elsevier Science (USA), 2003

https://doi.org/10.1016/B0-12-227240-4/00186-6

7. Mohammad Bin Amin, MD. Alauddin, and Dr. Mir Mohammad Azad. Business Transaction Processing System, in International Journal of Computer Information Systems, Vol. 4, No. 5, 2012, pp 11-15.

8. Megaventory. Cloud Inventory Management, Order Fulfillment, Manufacturing. Retrieved from https://www.megaventory.com/, 2009

9. Orderhive. Integrate \& Automate Order, Shipping And Inventory Management. Retrieved from https://my.orderhive.com/, 2015

10. Zoho Inventory. Inventory management software for growing businesses. Retrieved from https://inventory.zoho.com, 2009

11. Dix A., Finlay J., Abowd G.D., and Beale R. Human-Computer Interaction, Pearson Prentice Hall, 3rd ed., 2004

12. Setirek-Coskum A., and Tanrikulu Z. Intelligent Interactive Voice Response Systems and Customer Satisfaction, in International Journal of Advanced Trends in Computer Science and Engineering, vol. 8 no. 1, pp. 4-11, 2019. https://doi.org/10.30534/ijatcse/2019/02812019

13. Surendar G, and Rathnakar G., Accounting Profession - Role of Information Technology, in International Journal of Advanced Trends in Computer Science and Engineering, vol. 8 no. 1.2, pp. 154-160, 2019. 